\title{
Comparative study between ligature with thread or metallic clamping by means of laparoscopy with the purpose of experimental biliary obstruction in swines ${ }^{1}$
}

\author{
Estudo comparativo entre ligadura com fio ou clampeamento metálico por videolaparoscopia \\ para obstrução biliar experimental em suínos
}

\author{
Edmilson Rodrigo Daneze ${ }^{\mathrm{I}}$, Guilherme Azevedo Terra ${ }^{\mathrm{II}}$, Júverson Alves Terra Júnior ${ }^{\mathrm{III}}$, Aline Gomes de Campos ${ }^{\mathrm{IV}}$, Alex Augusto \\ da Silvav , Sílvia Azevedo Terra ${ }^{\text {II }}$

\begin{abstract}
IGraduate student, Veterinary Medicine Course, FAFRAM/FE, Ituverava-SP, Brazil. Helped with technical procedures, analysis and interpretation of data, acquisition of data and manuscript writing.

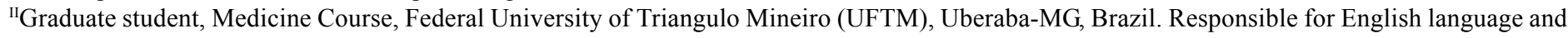
manuscript writing.

IIIMaster, Associate Professor, Department of Surgery, UFTM, Uberaba-MG, Brazil. Responsible for intellectual and scientific content of the study, technical procedures and critical revision.

${ }^{\mathrm{IV}}$ Master, Professor, Veterinary Medicine Course, FAFRAM/FE, Ituverava-SP, Brazil. Helped with technical procedures, analysis and interpretation of data, and necropsy examination.

${ }^{\mathrm{v}} \mathrm{PhD}$, Associate Professor, Department of Surgery, UFTM, Uberaba-MG, Brazil. Helped with technical procedures.

${ }^{V I} \mathrm{PhD}$, Professor, Veterinary Medicine course, FAFRAM/FE, Ituverava-SP, Brazil (In memorian). Responsible for intellectual and scientific content
\end{abstract} \\ of the study and necropsy examination.
}

\begin{abstract}
PURPOSE: To induce a total extra-hepatic obstructive jaundice in swines, by ligation of the common bile duct by laparoscopic surgery.

METHODS: Eight swines of the Landrace race, 36-day-old, originated from the same matrix, distributed in two groups. Group A: was used titanium metal clip to the common bile duct ligation in three animals; group B: were ligated with 2-0 cotton thread in five animals. RESULTS: The ligation of the biliary ducts was performed successfully in all animals, with easy identification of the common bile duct by laparoscopy. There weren't difficulties in the procedures, mainly due to the increased surgical field provided by the excellent quality of light and image of the appliance. The clinical signs of jaundice were evident in the animals in seven days. In group A, two animals showed bile duct perforation near the clip, probably due to ischemic necrosis, progressing to peritonitis and death. In group B, five animals showed obstructive jaundice without any amendment.

CONCLUSION: Under the conditions of this study, we therefore recommend the use of unabsorbed wires to experimental biliary obstruction, in order to avoid complications, such as ischemia and necrosis, followed by perforation of the wall of the bile ducts.
\end{abstract}

Key words: Laparoscopy. Cholestasis. Ischemia. Comparative Study. Swine.

\section{RESUMO}

OBJETIVO: Induzir um quadro de icterícia obstrutiva extrahepática total em suínos, através da ligadura no ducto colédoco por meio de cirurgia videolaparoscópica.

MÉTODOS: Oito suínos da raça Landrace, com 36 dias de idade, originários da mesma matriz, foram distribuídos em dois grupos. Grupo A: utilizou-se clipe metálico de titânio para ligadura do ducto colédoco em três animais; grupo B: foi feita a ligadura com fio de algodão 2-0 em cinco animais.

RESULTADOS: A ligadura da via biliar principal foi realizada com sucesso em todos os animais, com fácil identificação do colédoco por videolaparoscopia. Não houve dificuldades nos procedimentos, principalmente devido ao aumento do campo cirúrgico proporcionado pela qualidade de luz e imagem do aparelho. Os sinais clínicos indicativos de icterícia foram evidentes nos animais em sete dias. No grupo A, dois animais apresentaram perfuração coledociana junto ao clipe por provável isquemia e necrose, evoluindo com coleperitônio e óbito. No grupo B, os cinco animais apresentaram quadro de icterícia obstrutiva sem qualquer alteração.

CONCLUSÃO: Nas condições desse estudo, recomenda-se a utilização de fios inabsorvíveis para obstrução experimental das vias biliares, a fim de evitar complicações, como isquemia e necrose, seguida de perfuração da parede das vias biliares.

Descritores: Laparoscopia. Colestase. Isquemia. Estudo Comparativo. Suínos. 


\section{Introduction}

Cholelithiasis is one of the most common disorders of the biliary tree, considered an international public health problem, its prevalence is around $10 \%$ in national researchs $s^{1-4}$. The main risk factors for the development of gallstones in humans are age, heredity, parity and obesity; occurring mainly in people over 55 years, and a greater incidence among women ${ }^{5-8}$.

There are several conditions that, in humans and animals, can cause obstruction in the biliary tree, occurring cholestasis ${ }^{9-13}$. However, in recent years, there was an increase in the diagnosis of asymptomatic lithiasis due to upgrading diagnostic methods routinely performed in patients ${ }^{14-17}$. Because of its frequency, many researchs are conducted to expand the knowledge about the pathogenesis and improving treatment of this disease $\mathrm{e}^{14,15,18-24}$.

The treatment of biliary obstructions depends on the time between occurrence and diagnosis of the injury and, the type, extent and location of same in the bile ducts ${ }^{14,25}$, being the surgical treatment the most recommended ${ }^{2,26}$. In this context, the development and evolution of laparoscopic surgery have stimulated the execution of operative techniques increasingly complex; even considered safe, the procedure requires extensive anatomical knowledge and training aimed at reducing the incidence of postoperative complications ${ }^{25,27-32}$.

Assess any changes in liver and biliary tree due to biliary obstruction is of great importance, because it aids in clinical diagnosis of the patient, improving the quality and efficiency of treatment. For this, is required the development of experimental works, both to deepen knowledge of anatomy or in search for an ideal model for research as, also, for training and capacity of the surgeon to intervene surgically in the biliary tree ${ }^{18,20,21,25,27,28,33}$.

In order to seek a physiological and anatomical reconstruction more suitable for extensive lesions of the biliary tree, was proposed a study of biliary reconstruction by interposing a conduit derived from a segment of small intestine, similar to the one that Monti and collaborators have proposed for urinary diversion with continence mechanisms ${ }^{34,35}$. However, was necessary a experimental model enabling standardize a procedure that produces a pattern of obstructive jaundice by the extrahepatic biliary ligation, allowing for the previous acknowledgment of the surgical site, indicating the use of specific techniques to, a second moment, propose the reconstruction of the extrahepatic biliary tract. In this context, this research aimed to induce a total obstructive jaundice in swines, through the common bile duct ligation by laparoscopic surgery using 2-0 cotton thread or titanium metal clip, which compared the efficacy of the materials used and, also, description of the alterations observed in clinical evaluations, ultrasound examinations of the gallbladder and pathological analysis of the animals.

\section{Methods}

This project was evaluated by the Ethics Committee in Research of the Faculty Dr. Maeda Francisco and was approved under protocol n. 19/2008.

\section{Experimental delineation}

This research was developed in the Faculty Dr. Maeda Francisco (FAFRAM/FE), located in Ituverava-SP, Brazil, was used the structure of the swine farm and the laboratories and facilities of the Veterinary Hospital. Were utilized eight swines (Sus scrofa), Landrace race, with 36-day-old and average weight of 9,17 $( \pm 1,69)$ $\mathrm{kg}$, originating from the same matrix. They were followed from birth with individual clinical evaluations twice a week. The data collected and tests performed were stored in individual records.

The animals were divided randomly into two groups. Group A, with three animals subjected to bile duct obstruction by placing a metallic clip Titanium 9,0 mm long and 1,0 mm wide and, Group B, five animals that received ligature with 2-0 cotton thread.

\section{Ultrasound analysis}

Ultrasound examination pre-obstruction was made on the day preceding the procedure obstructive and the examination postobstruction, the same day of the correction of the biliary route; by food and water fasting and after ten minutes of sedation with acepromazine $(0,2 \mathrm{mg} / \mathrm{Kg} / \mathrm{IM})$. The images were recorded on video and printed paper. Were evaluated, for comparison purposes, the transverse and longitudinal diameters of the gallbladder.

\section{Anesthesia and surgical procedures}

The pre-operative procedures were common to all animals. The animals remained under water and food fasting for six hours. Arriving at the hospital received a cold shower bath for body cleansing, were sedated with acepromazine $(0,2 \mathrm{mg} / \mathrm{Kg} / \mathrm{IM})$ and, subsequently, underwent trichotomy and antisepsis of ventral abdominal region. After ten minutes of sedation, were taken to the operating room and accommodated on supine position on the operating table. The medial saphenous vein was catheterized for infusion of glucose-saline solution and administration of dissociative anesthetic based on the combination of tiletamine and zolazepam $(5,0 \mathrm{mg} / \mathrm{Kg} / \mathrm{IV})$, also being administered fentanyl $(0,025 \mathrm{mg} / \mathrm{Kg} / \mathrm{IV})$ and atropine sulfate $(0,5 \mathrm{mg} / \mathrm{Kg} / \mathrm{IV})$. Anesthesia was maintained with doses of one-third to half the original dose of the dissociative anesthetic. During surgery the animals were supplemented with oxygen by face mask.

Confirmed the anesthesia, laparoscopic procedure was initiated with a supra-umbilical midline incision of $1,0 \mathrm{~cm}$ to insert the Verres needle and perform the pneumoperitoneum, the intracavitary pressure was adjusted to $11,0 \mathrm{mmHg}$. Then four trocaters were placed: (1) two of 5,0 mm, located in a region caudal to the right costal margin and another at the level of right iliac fossa, (2) and two of 10,0 mm, one located 1,0 cm supra-umbilical and another caudal to the left costal margin (Figure 1).

During the procedure, were identified, isolated and dissected peri-hilar structures and performed laparoscopic common bile duct ligation as distal as possible (Figure 2), with intention to produce a total extra-hepatic obstructive jaundice. After the ligation procedure, hemostasis was reviewed, the cavity washed with saline preheated at a temperature $\pm 37.5^{\circ} \mathrm{C}$, dissolved the pneumoperitoneum, followed by laparorrhaphy with 2-0 cotton thread and 3-0 mononylon at skin. 


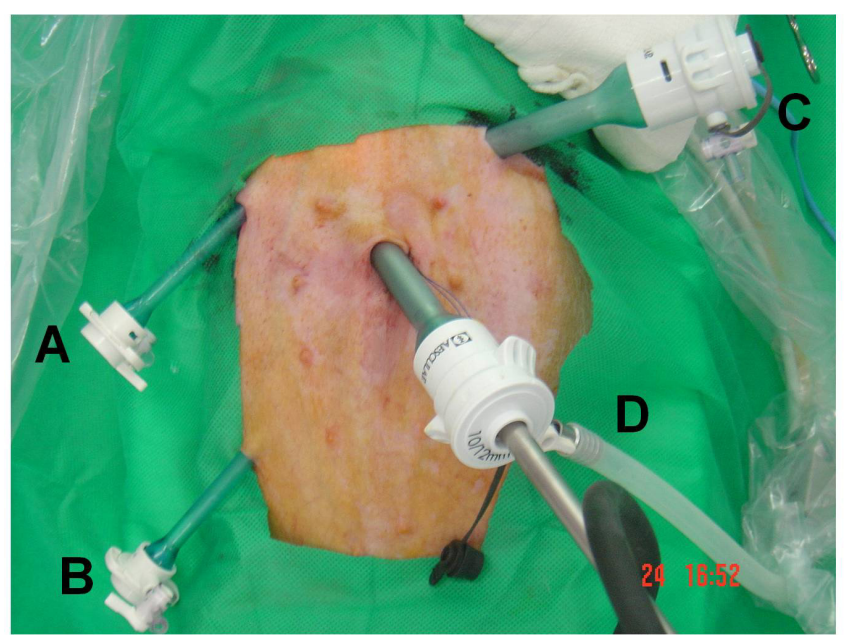

FIGURE 1 - Sites of placement of trocars in the abdomen of pigs subjected to procedure of the common bile duct ligation by laparoscopy. A - flow area to the right costal margin; B - level of the right iliac fossa; C - caudal to the left costal margin; D - pre-umbilical

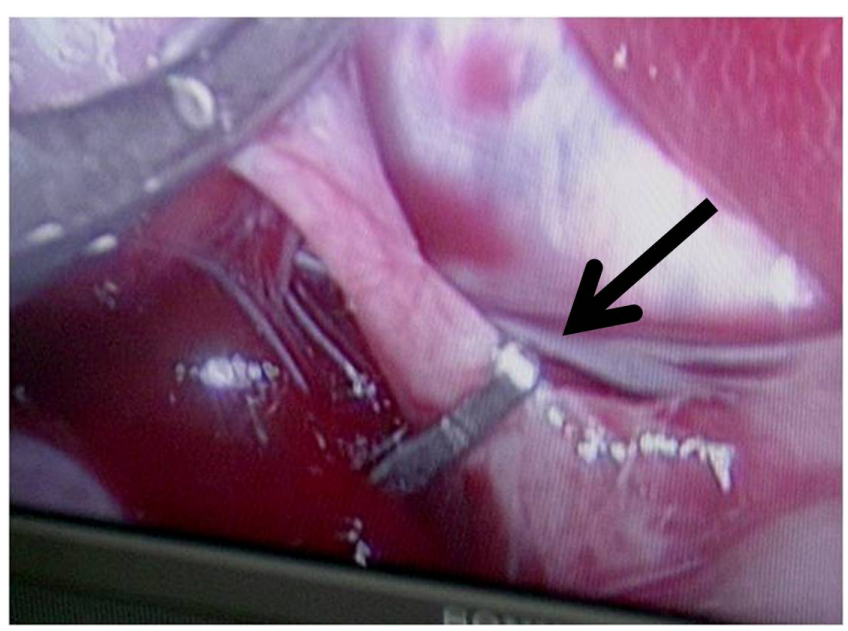

FIGURE 2 - Picture showing the site chosen for the common bile duct ligation aiming biliary obstruction in swine, as well as showing ligation performed with titanium metal clip (arrow)

Seven days after the obstructive procedure was performed laparotomy, by supra-umbilical incision at approximately $8.0 \mathrm{~cm}$, for inspection of the abdominal cavity (we used the same anesthetic protocol used for the procedure obstructive) and evaluating the site of ligation choledoco, as well as correction of the biliary pathway. Laparorrhaphy was made with 2-0 cotton thread and 3-0 mononylon at skin.

\section{Postoperative observations}

In the postoperative periods (obstruction and unobstruction) the animals were kept under constant care, to monitor the healing of surgical wounds and administering anti-inflammatory (dexamethasone, dose of $0,025 \mathrm{mg} / \mathrm{Kg} / \mathrm{IM} /$ day), analgesic (flunixin meglumine, dose of $2,2 \mathrm{mg} / \mathrm{Kg} / \mathrm{IM} /$ day) and preventive antibiotic (enrofloxacin, dose of $2,5 \mathrm{mg} / \mathrm{Kg} / \mathrm{IM} /$ day). The average weight of animals at the end of the experiment was $9,42( \pm 2,19) \mathrm{kg}$.

During the execution of the experiment two animals died and underwent autopsy examination.

\section{Results}

The main bile duct ligation was performed successfully in all animals, with easy identification of the bile duct by laparoscopic technique.

After the procedure of biliary obstruction, the most common clinical signs presented by the animals were strong yellow colored urine, icteric skin and mucous membranes in the sharp or discrete levels (Figure 3); faeces lighter shade than that observed before the ligation and hepatomegaly on palpation. By comparing the diameters ultrasound transverse and longitudinal gallbladder obtained in pre and post-obstructive postoperative, one can show considerable increase in the thickness of it (Figure 4).

With respect to cotton yarn and clip titanium, materials used for the ligated bile duct animals, was observed that the five ligations of the biliary tree performed with cotton thread presented clinical symptoms of obstructive jaundice without any degenerative changes of the common bile duct. Of the three ligation with metal clip, two died; one occurring two days after the obstructive procedure and the other four days after the procedure, during necropsy was observed with the drilling common bile duct clip and biliar peritonitis, the third animal presented with obstructive jaundice without any degenerative changes of the common bile duct.

During exploratory laparotomy, there was markedly increased liver volume in six animals, with moderately pale colored and markedly yellowish, firmer consistency, and increase in size and consistency of the gallbladder and extrahepatic bile ducts. In two necropsy, beyond these same changes hepatobiliary, areas of fibrinous inflammation were observed with adherence to intestinal segments in the Glisson's capsule, due to biliar peritonitis.

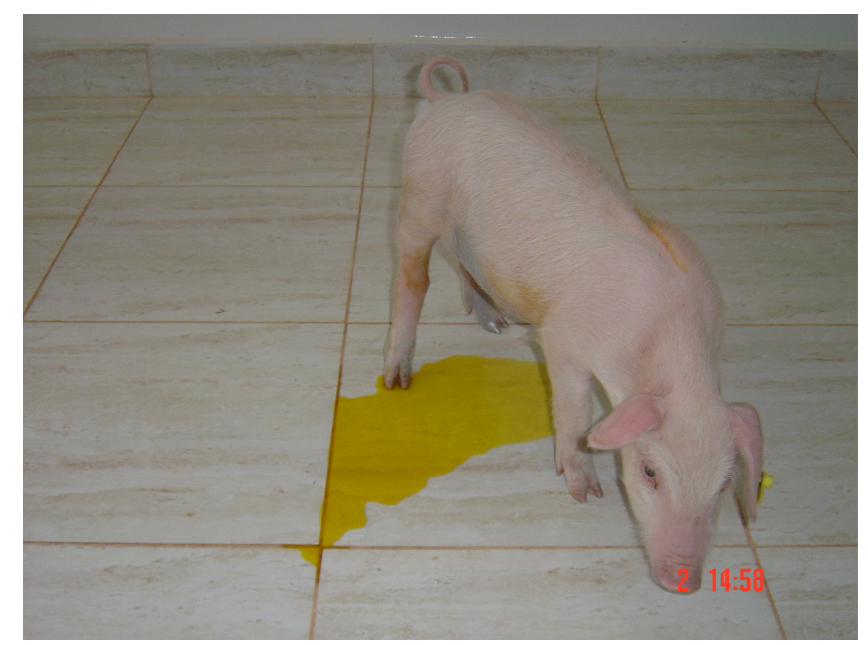

FIGURE 3 - Swine subjected to experimental biliary obstruction by ligation of the common bile duct, where there is jaundiced skin and intensely yellow color of urine 

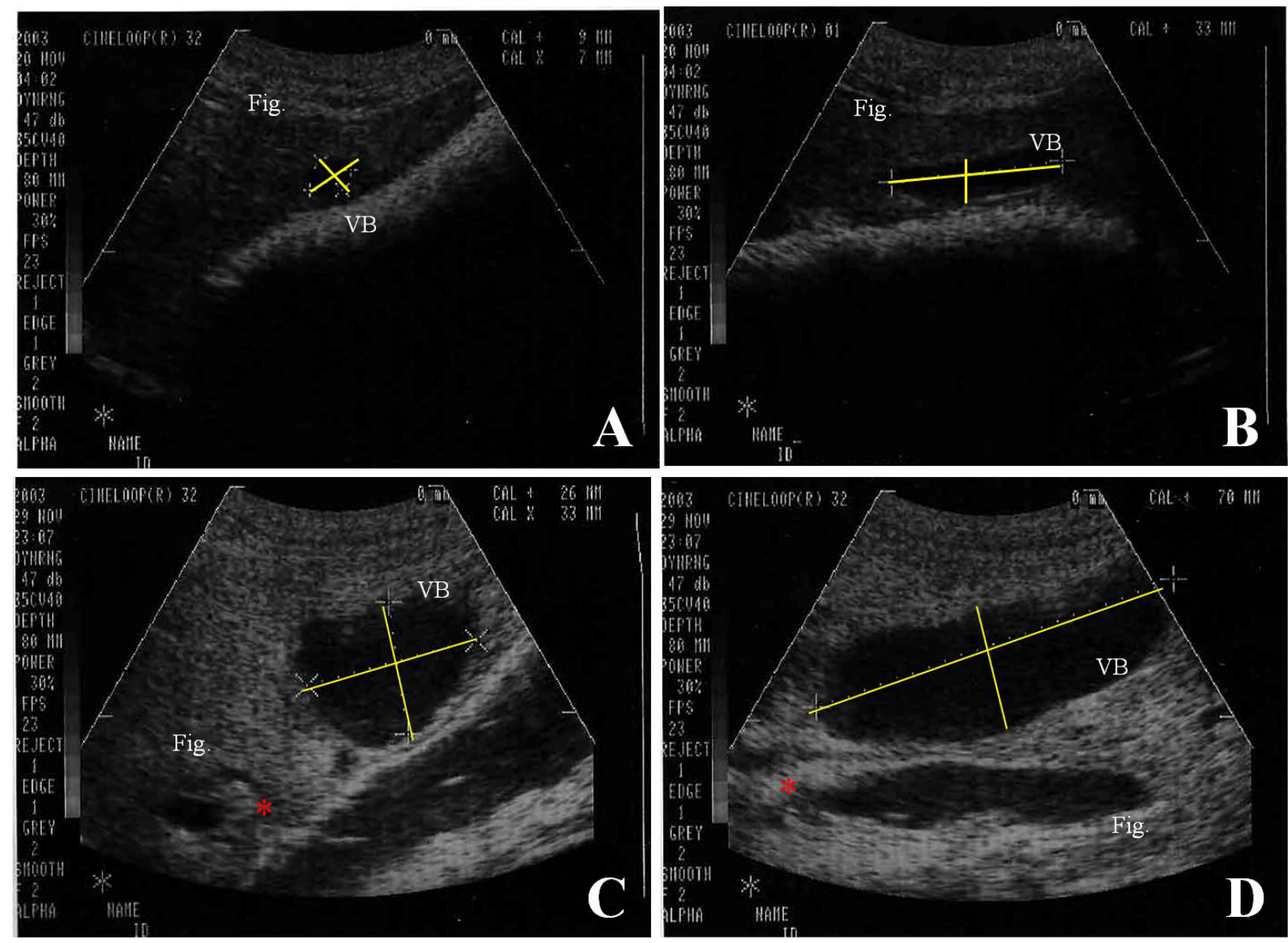

FIGURE 4 - Ultrasound images of gallbladder (lines) in swine subjected experimental biliary obstruction. A - transversal diameter pre-obstruction; B - longitudinal diameter pre-obstruction; C - transversal diameter post-obstruction; D - longitudinal diameter post-obstruction. Observe the increase in organ size (lines) when comparing A with $\mathrm{C}$ and $\mathrm{B}$ with $\mathrm{D}$. Is observed, also, increased echogenicity of hepatic parenchyma in C and D (*). FAFRAM/FE - 2010

\section{Discussion}

We used the swine (Sus scrofa domesticus) as an experimental animal because it is resistant, easy to handle and with a good possibility of standardization, beyond are considered a suitable animal model for diseases linked to lifestyle human ${ }^{33,36,37}$. When the physiology of humans is compared to the dog, rat, mice and other species used in testing these similarities are much more distant, however the swine model is the one with anatomical and functional characteristics closer to human, and its use in scientific research is an old practice ${ }^{38-41}$. Thus, these animals are frequently used in experimental studies associated to various morphological and functional changes that affect several organs and systems, including the liver and bile ducts, from simple histologic examination to more complex surgical procedures, providing a experimental model for developing or improving techniques and subsequent application in humans ${ }^{33,37,38,42}$.

In this context, the main bile duct ligation was performed successfully in all animals in this experiment, with easy identification of laparoscopic common bile duct, which is the most used and considered safe in treating disorders of the biliary tract, especially due to the low rate of complications and advantages such as less postoperative pain, shorter hospital stay and better

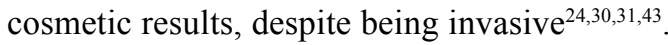

Obstructive procedures occurred without difficulty, mainly due to the visibility of the structures proper proportion through the screen provided by the device. This fact, which is associated with the maximization of the image of the organs in video monitors, allows you to define the exact site of action, providing safe interventions to vital structures, even in complicated $\operatorname{cases}^{28,29,44,45}$.

Experimental induction of extrahepatic cholestasis is a process that does not always succeed, requiring a high degree of technical quality, patience, concentration and continuous training ${ }^{46,47}$. But, seven days after the procedure for biliary obstruction, the animals showed strongly yellow urine, skin and mucous membranes icteric, ranging from mild to severe; stools lighter shade than that observed before ligation, so as to hepatomegaly palpation. Signs compatibles with what is described on cholestasis in humans ${ }^{1,48,49}, \operatorname{dogs}^{9,18}$, mices ${ }^{20}$ and $\operatorname{rats}^{22,23}$. However, in less time than that observed in other animal species researchs ${ }^{20,22}$. 
The development of jaundice justifies the color changes of skin and mucous membranes observed, because bilirubin is deposited in tissues such as in high concentrations ${ }^{49,50}$. In the case of urine, strong staining occurs due to increased concentration of bilirubin in the bloodstream, that pass through the glomeruli and is excreted, this is a characteristic change of cholestasis ${ }^{19}$. In the case of faeces, a reduction or absence of excretion of bilirubin in the intestinal lumen causes changes in faeces color making them clearer (reduction) or whitish (absence) $)^{50}$.

In questionable cases or require additional supporting information, or, even, for differential diagnosis, the interpretation of clinical signs should always be correlated with laboratory tests, ultrasound exams or other methods of diagnostic imaging ${ }^{2,13,47,51,52}$.

Ultrasound is a practical technique, fast and inexpensive, being considered as a screening assay in the initial evaluation of patients with suspected hepatobiliary tract disorders ${ }^{7,8,12,13,53}$, mainly due to its high sensitivity and specificity ${ }^{1,16}$. Through this examination, can visualize hepatomegaly in cases of cholestasis associated with obstruction, with the characteristic signs of increased volume of the organ and the presence of smooth margins, and there may be diffuse and increased echogenicity, and inadequate definition of the portal vessels; in biliary tract, is more common visualization increase of size in the gallbladder and dilation of ducts ${ }^{12,16,17}$. Data corroborate the ultrasound examination performed in the post-obstruction of this research, which we found a considerable increase in the diameter of the gallbladder.

With respect to cotton yarn and clip titanium there was not found publication about the use of these materials aimed to biliary obstruction in swines. However, some studies have been conducted to determine the safety of ligation of anatomical structures with titanium clips, such as Kerbl et al..$^{54}$, which revealed that the obstruction induced with titanium clips was safer than the ligatures made with silk or metal clasps. Nelson et al. ${ }^{55}$ and Beltran et al..$^{56}$, using swines as models, considered safe clips provided by the obstructions in the mesenteric vessels and cystic ducts, respectively, and these authors did not describe complications, such as rupture, in their experiments.

Soares et $a l .{ }^{57}$, when performing ligation with one, two or three titanium clips, or with cotton thread 0 (zero) in dogs, reported that there is no difference between the ligature made with cotton thread and made two or three titanium clips, showing similar resistance when subjected to the same pressure. However, Branco Filho et al. ${ }^{58}$, reported that of 45 human nephrectomies performed using ligation of the renal vessels with two titanium clips and cotton thread, there was need for further surgery in six hours for ligating the renal artery in one case, whose titanium clips were released. Maia et $a l .^{23}$, using only thread in the common bile duct ligation, in rats, results could obstructive, without describing complications during the experiment. Same situation described by Crema et al. ${ }^{18}$ in biliary obstruction experiment with dogs, and Dutra et al. ${ }^{59}$, also rats.

These data tally with what was found in this experiment, in which five ligation of the biliary tree with a cotton thread presented clinical symptoms of obstructive jaundice without any degenerative changes of the common bile duct. However, the three ligation with metal clip, two drilling common bile duct presented with the clip, developed with biliar peritonitis and consequently died after three and five days post-obstruction. This fact may have resulted from the procedure for biliary obstruction, which by compressing the common bile duct caused cholestasis with consequent distention of the ducts of the biliary ducts and gallbladder, and the same thinning of the wall, leading to compression of vessels responsible for irrigation with consequent progressive necrosis of hypoxic cell wall, causing rupture and leakage of bile into the peritoneal cavity and biliar peritonitis, taking the animal to death ${ }^{47,49,60-62}$.

Rupture of the gallbladder is usually associated with lesions of other structures such as mechanical irritation caused by stones in the wall of the organ, intravesicular pressure increase attributed to obstruction or severe inflammation and necrotizing ischemia, intravesicular pressure increase attributed to obstruction or severe necrotizing inflammation and ischemia, leading to biliar peritonitis and, consequently, evolution to death and increased mortality of traumatized ${ }^{9,11}$. Being that, among other causes, ischemia represents 5 at $10 \%$ of cases of acute cholecystitis. However, perforation of the gallbladder, biliar peritonitis, perivesicular abscess and biliary fistula are the main complications of acute cholecystitis ${ }^{63,64}$.

\section{Conclusions}

Under the conditions of the experiment was conducted, we concluded that swines represent a suitable experimental model of obstructive jaundice, being the interval of seven days enough for the animals develop the characteristic clinical signs of jaundice, beyond cholestasis noticeable at the ultrasound examination. However, the use of nonabsorbable wires proved to be more effective than titanium metallic clips in experimental procedures aimed at the common bile duct ligation in swines.

\section{References}

1. Silva RCO, Silva AL, Cioffi AC, Ferreira LL, Bez LG. Alterações histológicas da vesícula biliar litiásica: influência no diagnóstico e tratamento por videolaparoscopia. Rev Col Bras Cir. 2000;27:1-5.

2. Santos JS, Sankarankutty AK, Salgado Júnior W, Kemp R, Módena JLP, Elias Júnior J, Castro e Silva Júnior O. Colecistectomia: aspectos técnicos e indicações para o tratamento da litíase biliar e das neoplasias. Medicina (Ribeirão Preto). 2008;41:449-64.

3. Mantovani M, Leal RF, Fontelles MJ. Incidência de colelitíase em necropsias realizadas em hospital universitário no município de Campinas-SP. Rev Col Bras Cir. 2001;28:259-63.

4. Coelho JC, Bonilha R, Pitaki SA, Cordeiro RM, Salvalaggio PR, Bonin EA, Hahn CG, Soares RV, Milcheski DA. Prevalence of gallstones in Brazilian population. Int Surg. 1999;84:25-8.

5. Hermann RE. The spectrum of biliary stone disease. Am J Surg. 1989;158:171-3.

6. Sousa KPQ, Souza PM, Guimarães NG. Fatores antropométricos, bioquímicos e dietéticos envolvidos na litíase biliar. Comun Ciênc Saúde. 2008;19:261-70.

7. Anderi Júnior E, Pezzolo S, Speranzini MB, Waisberg J. Controvérsias na colecistectomia eletiva por colecistolitíase. Arq Med ABC. 1987; 10:15-7.

8. Torres OJM, Barbosa ES, Pantoja PB, Diniz MCS, Silva JRS, Czeczko NG. Prevalência ultra-sonográfica de litíase biliar em pacientes ambulatoriais. Rev Col Bras Cir. 2005;32:47-9. 
9. Arias D, Klima L, Rodriguez R, Cruz A, Bigeon G, Tortora M, Villanueva M, Stanchi N. Peritonitis biliar por colelitiasis con perforación de la vesícula biliar en un perro: presentación de un caso. Analect Vet. 2001;21:50-1.

10. Amsellem PM, Seim HB 3rd, MacPhail CM, Bright RM, Twedt DC, Wrigley RH, Monnet E. Long-term survival and risk factors associated with biliary surgery in dogs: 34 cases (1994-2004). J Am Vet Med Assoc. 2006;229:1451-7.

11. Góes-Júnior AMO, Albuquerque BCM, Magalhães AJL, Brito MVH. Ruptura traumática de vesícula biliar com eliminação de cálculo para a cavidade peritoneal. Rev Para Med. 2003;17:48-51.

12. Rodrigues ALS, Lobato MF, Braga CAR, MeguinsLC, Rolo DF. Empyema with giant dilatation of the gallbladder. ABCD Arq Bras Cir Dig. 2008;21:90-1.

13. Caly WR, Carpi G, Sica ACAR, Catapani WR. Calculose intra-hepática: desafio diagnóstico como causa de colestase. Relato de caso. GED. 2009;28:67-70.

14. Ahrendt AS, Pitt HA. Surgical therapy of iatrogenic lesions of biliary tract. World J Surg. 2001;25:1360-5.

15. Rauws EA, Gouma DJ. Endoscopic and surgical management of bile duct injury after laparoscopic cholecystectomy. Best Pract Res Clin Gastroenterol. 2004;18:829-46.

16. Bortoff GA, Chen MYM, Ott DJ, Wolfman NT, Routh WD. Gallbladder stones: imaging and intervention. Radiographics. 2000;20:751-66.

17. Gore RM, Thakrar KH, Newmark GM, Mehta UK, Berlin JW. Gallbladder imaging. Gastroenterol Clin North Am. 2010;39:265-87.

18. Crema E, Trentini EA, Llanos JC. Proposal of a new technique for bile duct reconstruction after iatrogenic injury: study in dogs and review of the literature. Acta Cir Bras. 2007;22:162-7.

19. Scott-Conner CEH, Grogan JB. The pathophysiology of biliary obstruction and its effect on phagocytic and immune function. J Surg Res. 1994;57:316-36.

20. Prado IB, Santos MHH, Lopasso FP, Iriya K, Laudanna AA. Cholestasis im a murine experimental model: lesions include hepatocyte ischemic necrosis. Medicina (São Paulo). 2003;58:27-32.

21. Dias MA, Ceneviva R, Elias Jr. J, Zuccoloto S, Baldo CF, Evora PRB. Liver histological, portal flow and plasmatic nitric oxide alterations caused by biliary obstruction and drainage in rats. Acta Cir Bras. 2008;23:2-7

22. Jorge GL, Leonardi LS, Boin IFSF, Silva Júnior OC, Escanhoela CAF. A new method for the experimental induction of secundary biliary cirrhosis in Wistar rats. Acta Cir Bras. 2001;16:75-81.

23. Maia ELC, Guimarães SB, Maia ACS, Maia JS, Vasconcelos PRL. Repercussões temporais da ligadura do ducto biliar principal em ratos Wistar. Acta Cir Bras. 2003;18:45-50.

24. Barkun JS, Barkun AN, Sampalis JS, Fried G, Taylor B, Wexler MJ, Goresky CA, Meakins JL. Randomised controlled trial of laparoscopic versus mini-cholecystectomy: a national survey of 4292 hospitals and an analysis of 77604 cases. Lancet. 1992;340:1116-9.

25. Schmidt SC, Langrehr JM, Schumacher G, Neuhaus P. Treatment of iatrogenic bile duct lesions from laparoscopic cholecystectomy. Rozhl Chir. 2005;84:567-72.

26. Rêgo REC, Campos T, Moricz A, Silva RA, Pacheco Júnior AM. Tratamento cirúrgico da litíase vesicular no idoso: análise dos resultados imediatos da colecistectomia por via aberta e videolaparoscópica. Rev Assoc Med Bras. 2003;49:293-9.

27. Sena JIN, Silva Filho AR, Pinheiro LGP. Colecistectomia videolaparoscópica experimental em cadáver humano - 70 casos. Rev Col Bras Cir. 2001;28:104-8.

28. Souza JAG, Barroso FL. Cirurgia videolaparoscópica: precauções e recomendações. Rev Col Bras Cir. 1998;25:415-21.

29. Salim MT, Cutait R. Complicações da cirurgia videolaparoscópica no tratamento de doenças da vesícula e vias biliares. ABCD Arq Bras Cir Dig. 2008;21:153-7.
30. Henriques AC, Pezzolo S, Gomes M, Godinho CA, Bagarollo CA. Colecistectomia videolaparoscópica ambulatorial. Rev Col Bras Cir. 2000;28:27-9.

31. Roque R, Freitas A, Pina A, Martinho A, Soares C, Messias H. Colecistectomia laparoscópica: cirurgia de ambulatório. Acta Med Port. 2007;20:407-12.

32. Walsh RM, Henderson JM, Vogt DP, Brown N. Long-term outcome of biliary reconstruction for bile duct injuries from laparoscopic cholecystectomies. Surgery. 2007;142:450-7.

33. Christensen M, Laursen HB, Rokkjaer M, Jensen PF, Yasuda Y, Mortensen FV. Reconstruction of the common bile duct by a vascular prosthetic graft: an experimental study in pigs. J Hepatobiliary Pancreat Surg. 2005;12:231-4.

34. Monti PR, Lara RC, Dutra MA, Carvalho JR. New techniques for construction of efferent conduits based on the Mitrofanoff principle. Urology. 1997;49:112-5.

35. Monti PR, Carvalho JR, Arap S. The Monti procedure applications and complications. Urology. 2000;55:616-21.

36. Almond GW. Research applications using pigs. Vet Clin North Am Food Anim Pract. 1996;12:707-16.

37. Torres OJM, Pantoja PB, Barbosa ES, Barros CA, Servin ETN, Servin SCN. Alterações hemodinâmicas durante transplante hepático ortotópico experimental em suínos. Acta Cir Bras. 2008;23:135-9.

38. Raudales JC, Zago AJ, Kosachenco BG, Benetti JC, Dallarosa D, Dreyer C, Ferst JG, Bortolini MA, Ramos SP, Zago AC. Modelo experimental de reestenose intrastent em artérias coronárias de suínos: efeito do implante de stent sobredimensionado. Rev Bras Cardiol Invas. 2010;18:55-61.

39. Narayanaswamy M, Wright KC, Kandarpa K. Animal models in atherosclerosis, restenosis, and endosvascular graft research. J Vasc Interv Radiol. 2000;9:5-17.

40. Bustard LK, McClellan RO. Use of pigs in biomedical research. Nature. 1965;208:531-5.

41. Wolf YG, Gertz D, Banai S. Animal models in syndromes of accelerated arteriosclerosis. Ann Vasc Surg. 1999;13:328-38.

42. Petrucci O, Oliveira PPM, Carmo MR, Vieira RW, Braile DM. Standardization of an isolated pig heart preparation with parabiotic circulation: methodological considerations. Braz J Med Biol Res, 2003;36:649-59.

43. Machado MAC, Rocha JRM, Herman P, Montagnini AL, Machado MCC. Tratamento laparoscópico de coledocolitíase. Arq Gastroenterol. 2000;37:183-6.

44. Gollop TR, Ruiz Filho AU, Santos AG, Bianchi RF, Rossi AGZ. Cirurgia por orifícios naturais: novo conceito em cirurgia minimamente invasiva. Einstein. 2010;8:124-6.

45. Engler-Pinto Júnior P, Arab-Fadúl R, Bresciane C, Sobreira R, Souza LJ, Gama-Rodrigues J. Diagnóstico videolaparoscópico de agenesia da vesícula biliar em paciente adulto sintomático. An Paul Med Cir. 1996;123:29-33.

46. Battochio APR, Santos AG, Silva CRM, Rocha AS, Coelho CAR. Adaptação do modelo experimental de colestase extra-hepática em ratos jovens. Acta Cir Bras. 2004;19:70-3.

47. Quaresma AB, d'Acampora AJ, Tramonte R, Farias DC, Joly FS. Estudo bioquímico do sangue de ratos após ligadura do ducto hepático direito. Arq Catar Med. 2003;32:21-32.

48. Franchi-Teixeira AR, Antoniali F, Boin IFSF, Leonardi LS. Icterícia obstrutiva: conceito, classificação, etiologia e fisiopatologia. Medicina (Ribeirão Preto). 1997;30:159-63.

49. Silva Júnior OC, Ceneviva R, Rizzo CC, Sankarankutty AK, Granato RG, Menegazzo LAG. Alterações hepáticas na icterícia obstrutiva. Medicina (Ribeirão Preto). 1997;30:165-72.

50. Martinelli ALC. Icterícia. Medicina (Ribeirão Preto). 2004;37:246-52. 51. Demartines N, Eisner L, Schnabel K, Fried R, Zuber M, Harder F. Evaluation of magnetic resonance cholangiography in the management of bile duct stones. Arch Surg. 2000;135:148-52. 
52. Campos T, Parreira JG, Moricz A, Rego REC, Silva RA, Pacheco Júnior AM. Fatores preditivos de coledocolitíase em doentes com litíase vesicular. Rev Assoc Med Bras. 2004;50:188-94.

53. Bispo M, Pina PR, Sousa S, Seves I, Moura MLC, Graça JP. Colangite esclerosante primária: uma forma de apresentação potencialmente fatal. J Port Gastrenterol. 2007;14:236-40.

54. Kerbl K, Chandhoke PS, Clayman RV, McDougall E, Stone AM, Figenshau RS. Ligation of the renal pedicle during laparoscopic nephrectomy: a comparison of staples, clips, and sutures. J Laparoend Surg. 1993;3:9-12.

55. Nelson MT, Nakashima M, Mulvihill SJ. How secure are laparoscopically placed clips? An in vitro and in vivo study. Arch Surg. 1992;127:718-20

56. Beltran KA, Foresman PA, Rodeheaver GT. Quantitation of force to dislodge endoscopic ligation clips: Endoclip II vs. Ligaclip ERCA. J Laparoend Surg. 1994;4:253-6.

57. Soares AL, Goldenberg S, Novo NF, Lima CAP. Aterial titanium clip and stitch ligation in dogs: experimental study in a pump machine. Acta Cir Bras. 2001;16:218-25.

58. Branco Filho AJ, Branco AW, Kondo W, Maciel RF, Carvalho RM, Garcia MJ. Controle dos vasos renais usando clips vasculares e fio cirúrgico em nefrectomias vídeo assistidas de doadores vivos. Rev Col Bras Cir. 2005;32:36-40.
59. Dutra RA, Santos JS, Araújo WM, Simões MV, Paixão-Becker AN, Neder L. Evaluation of hepatobiliary excretion and enterobiliary reflux in rats with biliary obstruction submitted to bilioduodenal or biliojejunal anastomosis. Dig Dis Sci. 2008;53:1138-45.

60. Ferreira MA, Santos JS, Dutra RA, Salgado Júnior W, Kemp R, Domiciano C, Ramalho LNZ, Sankarankutty AK, Castro e Silva Júnior O. Bilioduodenal anastomosis in rats with extra-hepatic biliary obstruction is followed by lesions ischemia and reperfusion-induced. Acta Cir Bras. 2008;23:47-52.

61. Vidal EI, Costa FFC, Coeli NM, Souza AP. Perfuração espontânea de colédoco: relato de um caso em adulto. Rev Col Bras Cir. 1991;18:67-9. 62. Soldá SC, Rodrigues FCM, Silva RA, Rasslan S. Coleperitônio após colecistectomia convencional tratado por via laparoscópica. Rev Col Bras Cir. 1998;26:69-71.

63. Takada T, Kawarada Y, Nimura Y, Yoshida M, Mayumi T, Sekimoto M, Miura F, Wada K, Hirota M, Yamashita Y, Nagino M, Tsuyuguchi T, Tanaka A, Kimura Y, Yasuda H, Hirata K, Pitt HA, Strasberg SM, Gadacz TR, Bornman PC, Gouma DJ, Belli G, Liau KH. Background: Tokyo Guidelines for the management of acute cholangitis and cholecystitis. J Hepatobiliary Pancreat Surg. 2007;14:1-10.

64. Strasberg SM. Acute calculous cholecystitis. N Engl J Med. 2008;358:2804-11.

\section{Correspondence:}

Júverson Alves Terra Júnior

Departamento de Cirurgia

Universidade Federal do Triângulo Mineiro (UFTM)

Av. Getúlio Guaritá, s/n

38025-440 Uberaba - MG Brasil

Tel.: (55 34)3318-5228

juverson@terra.com.br

Confict of interest: none

Financial source: none

${ }^{1}$ Research performed at Swine Sector and Department of Veterinary Surgery of Veterinary Hospital, Faculty Dr. Francisco Maeda (FAFRAM/FE), Ituverava-SP, Brazil.

Presented at the XII National Congress on Experimental Surgery of the Brazilian Society for Development of Research in Surgery-SOBRADPEC, October 26-29, Ribeirao Preto-SP, Brazil. 